\title{
Effects of the seed predator Acanthoscelides schrankiae on viability of its host plant Mimosa bimucronata
}

\author{
CAMILA A. TOMAZ, DÉBORA KESTRING and MARCELO N. ROSSI
}

Departamento de Botânica, IB, Universidade Estadual Paulista (Unesp), Botucatu, São Paulo, Brazil.

\begin{abstract}
Seeds of Mimosa bimucronata are heavily infested (pre-dispersal predation) by the bruchid beetle Acanthoscelides schrankiae in Brazil. In this study, firstly we set up experiments to assess seed germination under seven and six different light and temperature regimes, respectively, and then we evaluated the ability of seeds to germinate after predation. We tested the hypothesis that the non-predated seeds from infested fruits may respond differently when set for germination than those seeds of non-infested fruits. We also hypothesized that predation may increase the production of unviable seeds. Seeds under 18 hours of light presented the highest percentage of germination, and the alternating temperature $20-30{ }^{\circ} \mathrm{C}$ was considered as optimum for germination (abnormal seedlings were not considered as a successful germination). Germination of seeds from non-infested fruits was significantly higher than germination of non-predated seeds from infested fruits, and predation also caused a significant increase in the proportion of dead seeds. Our results also show a positive correlation between proportions of unviable seeds and predated seeds. These results demonstrated that seeds of $M$. bimucronata are strongly affected by predation because predated seeds did not germinate and non-predated seeds had their viability reduced when located in infested fruits, supporting our hypothesis.
\end{abstract}

Key terms: Acanthoscelides schrankiae, Bruchidae, germination, Mimosa bimucronata, seed predation.

\section{INTRODUCTION}

Herbivory is defined as the consumption of plants by animals, and encompasses different types of interactions. For example, seed and seedling herbivory are predatory interactions because herbivores kill individuals in the population (Strauss and Zangerl, 2002), and animals that feed mainly or exclusively on seeds are termed granivores (Hulme and Benkman, 2002). Granivory can be extremely important for limiting the size of plant populations (topdown effects) because high mortality rates are expected when predation is severe, decreasing seedling densities in future generations (Crawley, 1992; Hulme, 1998; Crawley, 1997; Gurevitch et al., 2002). Therefore, granivores play a crucial role on regeneration, colonization ability, and spatial distribution of plants (Louda et al., 1990; Myster and Pickett, 1993; Hulme, 1997; Castro et al., 1999; Forget et al., 1999; Picó and Retana, 2000).

Among the most important seed predators are the insects, mainly those from Coleoptera, Diptera, Lepidoptera, and Hemiptera orders (Janzen, 1971). Bruchid (Coleoptera) beetles (62 genera worldwide) are seed-eating insects (larval stage) that feed in the seeds of about 34 plant families, and many species are of considerable economic importance, inflicting damages on cultivated plants (Cardona, 1989; Baier and Webster, 1992; Nápoles, 2002). As most bruchids are host specific, they naturally regulate plant populations by killing their seeds, giving no options for plants to disperse (Janzen, 1975; Southgate, 1979; Nápoles, 2002). The bruchid beetle

Corresponding author: Marcelo N. Rossi, Departamento de Botânica, IB, Universidade Estadual Paulista (Unesp), Botucatu, São Paulo, CEP: 18-618-000, Brazil, Tel.: +55-14-38116265, Fax: +55-14-38153744, e-mail: mnrossi@ibb.unesp.br 
Acanthoscelides schrankiae (Horn) feeds in the seeds of twelve plant species (10 Mimosa, 1 Acacia, and 1 Schrankia) even though there are new host plants to be discovered, mainly in tropical areas (Nápoles, 2002), and this species can be found in Bahamas, Ecuador, the United States, Mexico, the Dominican Republic, Venezuela, and Brazil (JR Nápoles, personal communication). Very little is known about this bruchid beetle as information in the literature is rather scant (Johnson, 1983, 1990; Silva et al., 2007) and the effects of predation on seed germination by this bruchid are still unknown.

Mimosa bimucronata (DC.) Kuntze (Fabaceae: Mimosoideae) is an endemic perennial tree (or shrub) from Brazil, Paraguay, Argentina, and Uruguay (Burkart, 1959), reaching around $10 \mathrm{~m}$ high with intense ramification of branches. This plant grows along wetlands and riverbanks, and on the shore of lakes, where few individuals can form dense aggregations (Lorenzi, 2000). Mimosa bimucronata is an important agent for restoration of degraded areas, and produces good quality wood for charcoal utilization (Reitz et al., 1983; Marchiori, 1993). However, $M$. bimucronata is also an important weed when dense populations grow in pasture areas (Lorenzi, 2000) because its large branches with thorns can hamper cattle from accessing water and fresh grass. Moreover, only a few grasses can grow below the canopy of these plants due to shading, which causes loss of areas for grass management. Most $M$. bimucronata seeds (located in craspedium fruits) have a semi-permeable seed coat and scarification (mechanical or chemical) increases the speed of germination (Ferreira et al., 1992; Ribas et al., 1996). Low humidity usually decreases their germination potential (Ferreira, 1976; Ferreira and CallegariJacques, 1980), and either hot water at $80^{\circ} \mathrm{C}$ (Ribas et al., 1996) or sulphuric acid application for 10 minutes (Fowler and Carpanezzi, 1998) are satisfactory methods to increase the performance of seed germination. Despite the economic importance of $M$. bimucronata, little is known about its biology, ecology, and associated organisms. Thus, as their seeds are heavily infested by A. schrankiae in Brazil it is worthwhile to understand the effects of seed predation on germination.

As $A$. schrankiae kills $M$. bimucronata seeds during consumption not allowing germination (see Results), we tested the hypothesis that the non-predated seeds from infested fruits may respond differently than those seeds of non-infested fruits when set for germination because differences in resource allocation may occur. Therefore, dry weights and water contents of nonpredated seeds from infested and noninfested fruits were compared. As differences in seed germination between infested and non-infested fruits were expected, we investigated whether predation by $A$. schrankiae reduces seed quality by increasing the proportion of unviable seeds in $M$. bimucronata plants. Although there are some studies focused on seed technology of $M$. bimucronata, regional differences in seed germination are usually expected (Cruz et al., 2003; Schütz and Rave, 2003). Thus, as there are no published studies focusing on seed germination of this plant species in our locality (state of São Paulo, city of Botucatu), we finally set up experiments to assess seed germination under seven and six different light and temperature regimes, respectively, so as to determine the best environmental conditions for seed germination.

\section{MATERIAL AND METHODS}

\section{Study site and collection of fruits}

Seeds of $M$. bimucronata were randomly collected from twenty plants selected for their uniform size, located in the city of Botucatu-SP (Brazil), at the Faculdade de Ciências Agrárias of the Universidade Estadual Paulista - UNESP (22 $2^{\circ} 50$ ' 52" S; $\left.48^{\circ} 25^{\prime} 46^{\prime \prime} \mathrm{W}\right)$. The climate in the area is typically mesotherm of dry winter (Koeppen - Cwb) (Carvalho et al., 1983), and all plants grow by a lake, surrounded mainly by grasses. After collection, all 
fruits were exposed to fresh air in a shady environment for drying. After drying, fruits were separated in two groups (A and B) to set up the experiments. Fruits from groups $A$ and $B$ were arranged to evaluate the effects of light and temperature on seed germination, and the effects of seed predation on germination, respectively.

\section{Effects of light and temperature on seed germination}

Firstly, the infested and non-infested fruits were separated in the laboratory and, after dissection, non-predated seeds (we designated all non-predated seeds viable seeds) from non-infested fruits were put into transparent Gerbox containers $(11 \mathrm{~cm} \mathrm{x} 11$ $\mathrm{cm} \times 4 \mathrm{~cm}$ ) lined with soaked (distilled water) wet filter papers. The percentage of germination was evaluated under five constant $\left(15^{\circ} \mathrm{C}, 20^{\circ} \mathrm{C}, 25^{\circ} \mathrm{C}, 30^{\circ} \mathrm{C}\right.$, and $\left.35^{\circ} \mathrm{C}\right)$ and an alternating temperature $\left(20-30^{\circ} \mathrm{C}\right)$, and also under seven light conditions ( $0 \mathrm{~h}$, $2 \mathrm{~h}, 4 \mathrm{~h}, 8 \mathrm{~h}, 12 \mathrm{~h}, 18 \mathrm{~h}$, and $24 \mathrm{~h})$. The alternating temperature had the light period corresponding to the highest temperature. Each treatment was repeated 8 times with 25 seeds for each replicate (one Gerbox). Gerbox containers were wrapped in transparent plastic bags to prevent water losses. Sulphuric acid was applied to all seeds for 10 minutes to increase the speed of seed germination (Fowler and Carpanezzi, 1998). For the temperature and light tests, seeds were kept under 8 hours of white light [fluorescent $15 \mathrm{~W}$ lamps $\left(78 \mu \mathrm{mol} \mathrm{s}{ }^{-1} \mathrm{~m}^{-2}\right)$ ] and $25^{\circ} \mathrm{C}$, respectively (Brasil, 1992). It is important to mention that the abnormal seedlings were not considered as a successful germination. Therefore, the abnormal seedlings were excluded from the calculation of the percentage of germination. Plants that presented shoots without roots, and vice-versa, were classified as abnormal seedlings.

To evaluate if water contents (\%) of seeds were homogeneous, immediately before each germination test, seeds were put into iron cans (50 seeds per can) and weighed with a semi-analytical scale (wet weight). After weighing, seeds were dried $\left(105 \pm 3{ }^{\circ} \mathrm{C}\right.$ for 24 hours) and reweighed
(Brasil, 1992). Therefore, water contents were calculated by subtracting the wet from the dry weights. Each can corresponded to a replicate, and twelve and fourteen replicates (equivalent to two replicates per temperature and light regime) were adopted before temperature and light experiments, respectively.

Two ANOVA (Zar, 1999) were run to compare the mean percentage of germination between the different temperatures and light regimes, respectively, and paired comparisons of means were run by the Least Significant Difference $(L S D)$ test (Zar, 1999) when appropriate. The Student's $t$-test (Zar, 1999) was run to compare the mean percentage of water contents between seeds used for light and temperature experiments. For statistical analyses, germination and water contents data were transformed (arcsine $\sqrt{\text { prop}}$ ).

\section{Effects of seed predation}

Likewise, we first separated the infested from the non-infested fruits, but after dissection, predated and non-predated seeds were removed from the fruits. Viable seeds from infested and non-infested fruits were then separated and put into transparent Gerbox containers lined with wet filter papers. The percentage of germination and the percentage of dead seeds from infested and non-infested fruits were compared by the Student's $t$-test (data in arcsine $\sqrt{ }$ prop). This experiment was carried out at the alternating temperature $20-30^{\circ} \mathrm{C}$ under 18 hours of light, since we considered these conditions as optimum for seed germination (see Results). Each treatment was repeated 15 times with 25 seeds for each replicate, and Gerbox containers were wrapped with transparent plastic bags to prevent water losses. Sulphuric acid was applied for 10 minutes on all seeds to increase the speed of seed germination. Immediately before the germination tests, water contents of seeds were determined as described above, and 20 replicates were considered for each treatment (viable seeds from infested and non-infested fruits). The Student's $t$-test was run (data in arcsine $\sqrt{ }$ prop) to compare 
the mean percentage of water contents of seeds. To evaluate if seeds damaged by $A$. schrankiae were able to germinate, the predated seeds were also put into Gerbox containers ( 8 replicates with 25 seeds each) at the optimum temperature and light conditions estimated. Sulphuric acid was not applied on seeds in this case.

After all germination tests, we returned to the study site and 200 new fruits were collected at random from each selected plant; therefore, each plant represented a replicate $(4,000$ fruits distributed in 20 replicates) for statistical analyses. Again, we separated non-predated seeds from the infested and non-infested fruits; however, in this case, the number of unviable seeds was also recorded. We considered as unviable those aborted seeds that presented irregular development during fruit maturation. Usually, unviable seeds of $M$. bimucronata present dark color and have much less weight than viable seeds, being unable to germinate. For the infested fruits, the mean number of seeds attacked per fruit was also estimated. All viable seeds from each plant were counted and put into small paper bags separating those from infested and non-infested fruits. After that, seeds were dried $\left(105 \pm 3^{\circ} \mathrm{C}\right.$ for 24 hours $)$ and then weighed with a semi-analytical scale. Therefore, dry weights of viable seeds were estimated for each plant. Due to the unequal number of viable seeds, the dry weight was divided by the number of weighed seeds (weight estimated for one seed) and these values were used for statistical analyses. To estimate the proportion of unviable seeds, the number of unviable seeds recorded for each plant was divided by the total number of non-predated seeds per plant, and these calculations were computed only for seeds from infested fruits. The Student's $t$-test was run to compare the mean dry weights of viable seeds between infested and noninfested fruits. Finally, we estimated the proportion of predated seeds per plant $\left(\mathrm{n}^{\circ}\right.$ of predated seeds/total $\mathrm{n}^{\circ}$ of seeds), and a correlation analysis (Zar, 1999) between the proportion (arcsine $\sqrt{ }$ prop) of predated seeds and the proportion (arcsine $\sqrt{ }$ prop) of unviable seeds among plants was computed.

For all experiments, seven-day-old germinated seeds were used for recording the percentage of germination, and we considered as germination the emergence of $2 \mathrm{~mm}$ of radicle.

\section{RESULTS}

Comparison of mean percentages of seed germination between the different temperatures did not show significant differences (Table 1). However, for the light levels investigated, significant differences in seed germination were observed (Table 1). Seeds under 18 hours of light presented the highest percentage of germination, and germination was reduced to zero in full darkness (Fig. 1). Germination was also significantly reduced for seeds under 24 hours of light (Fig. 1). In the absence of light, we found $98 \%$ of abnormal seedlings and $2 \%$ of dead seeds, justifying zero percent of germination in this condition. Under 24 hours of light, the percentage of abnormal seedlings was also relatively high $(27.5 \%)$. Although significant differences between light regimes were observed, seeds responded well from 2 to 18 hours of light, since the percentages of germination were similar (Fig. 1). Seeds were very homogenous for

TABLE I

Results from two ANOVA comparing the mean percentages of germination among the different temperatures and light regimes

\begin{tabular}{lcccc}
\hline Source of variation & Degrees of freedom & Mean Square & F & P-values \\
\hline$\%$ Germination (temperatures) & 5 & 0.0495 & 1.4097 & 0.2405 \\
$\%$ Germination (light levels) & 6 & 1.6140 & $80.2421<$ & $<0.001$ \\
\hline
\end{tabular}


light and temperature experiments as their mean water contents did not differ statistically $(t=-0.9803 ; d f=24 ; P=$ $0.3367 ; N=14$ and $\mathrm{N}=12$, for light and temperature treatments, respectively).

Even though seed germinability did not differ between the temperatures tested, the alternating temperature $20-30^{\circ} \mathrm{C}$ was considered as optimum for germination because it presented the highest mean percentage of germination (Fig. 2). Therefore, the alternating temperature 20$30^{\circ} \mathrm{C}$ under 18 hours of light was considered as optimum for seed germination, explaining the evaluation of the effects of seed predation under these conditions. The mean water contents of seeds from infested and non-infested fruits did not differ statistically $(t=-0.9606 ; d f=$ 2; $P=0.4381 ; N=2$, for each treatment). However, the mean percentage of germination of viable seeds from noninfested fruits $(87.73 \% \pm 11.36 \%)$ [Mean $( \pm$ Standard Deviation)] was significantly higher than the mean percentage of germination of viable seeds from infested fruits $(59.73 \% \pm 13.39 \%)(t=-6.006 ; d f=$
28; $P<0.001 ; N=15$ for each treatment). Predation by $A$. schrankiae also caused an increase in the proportion of dead seeds, as the mean percentage of dead seeds was significantly higher in infested $(26.4 \% \pm$ $10.56 \%)$ than in non-infested fruits $(5.6 \% \pm$ $6.56 \%)(t=-6.640 ; d f=28 ; P<0.0001 ; N$ $=15$ for each treatment). Predated seeds were strongly affected because we observed that all predated seeds did not germinate. For all collected fruits (infested + noninfested) a mean of $6.39[ \pm 1.23(\mathrm{SD})]$ seeds per fruit was found, and the infested fruits presented a mean of $3.88[ \pm 1.55$ (SD)] predated seeds per fruit.

Although the mean dry weights of viable seeds from infested and non-infested fruits did not differ statistically $[t=0.879 ; d f=34$; $P=0.3857(\mathrm{~N}=20$ and $\mathrm{N}=16$ for infested and non-infested fruits, respectively, as four plants did not present non-infested fruits)], predation by $A$. schrankiae may affect the production of unviable seeds because a significant positive correlation between the proportion of unviable seeds and the proportion of predated seeds was observed among trees (Fig. 3).

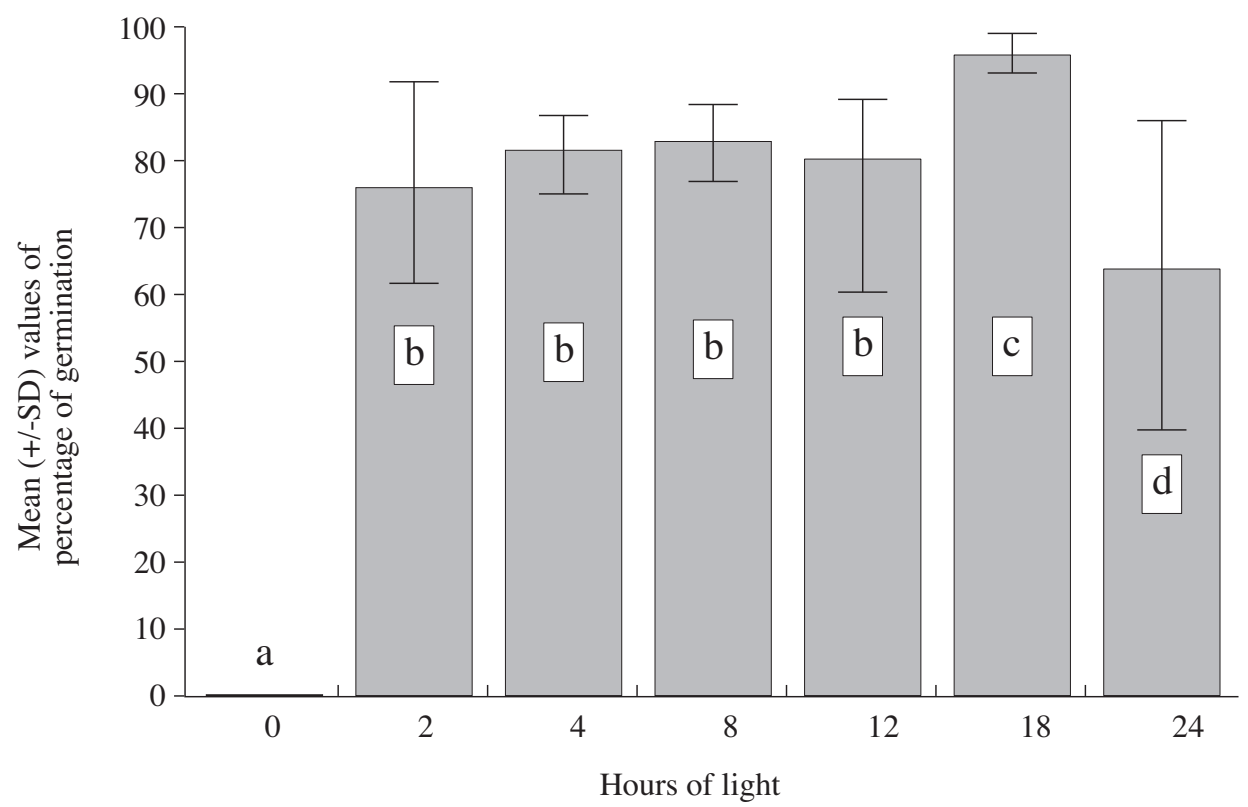

Figure 1: Mean ( \pm Standard Deviation) values of percentage of germination of seeds under different light regimes. Means followed by different letters differed statistically by the Least Significant Difference $(L S D)$ test $(P<0.05)$. Abnormal seedlings were not considered in the calculations. 


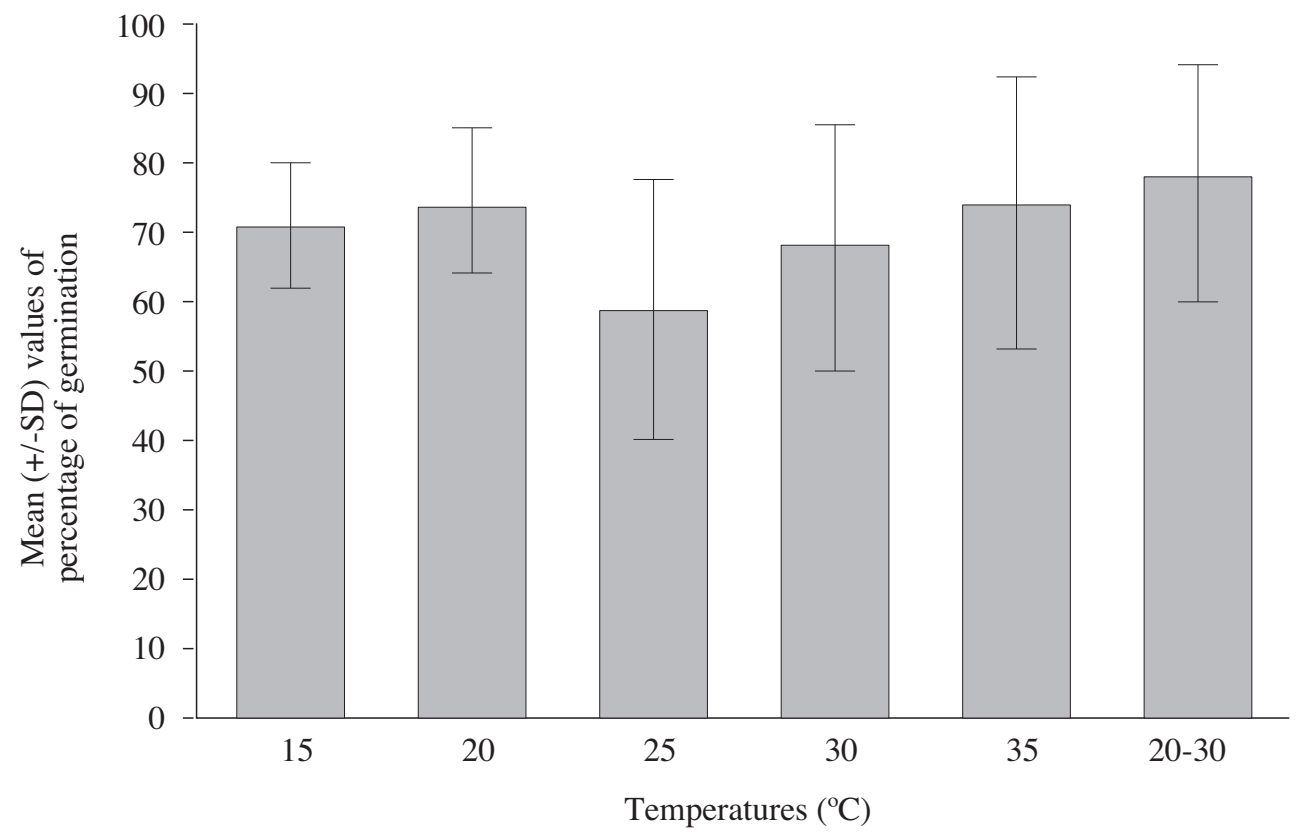

Figure 2: Mean ( \pm Standard Deviation) values of percentage of germination of seeds under different temperatures. Means did not differ statistically by ANOVA test $(P>0.05)$. Abnormal seedlings were not considered in the calculations.

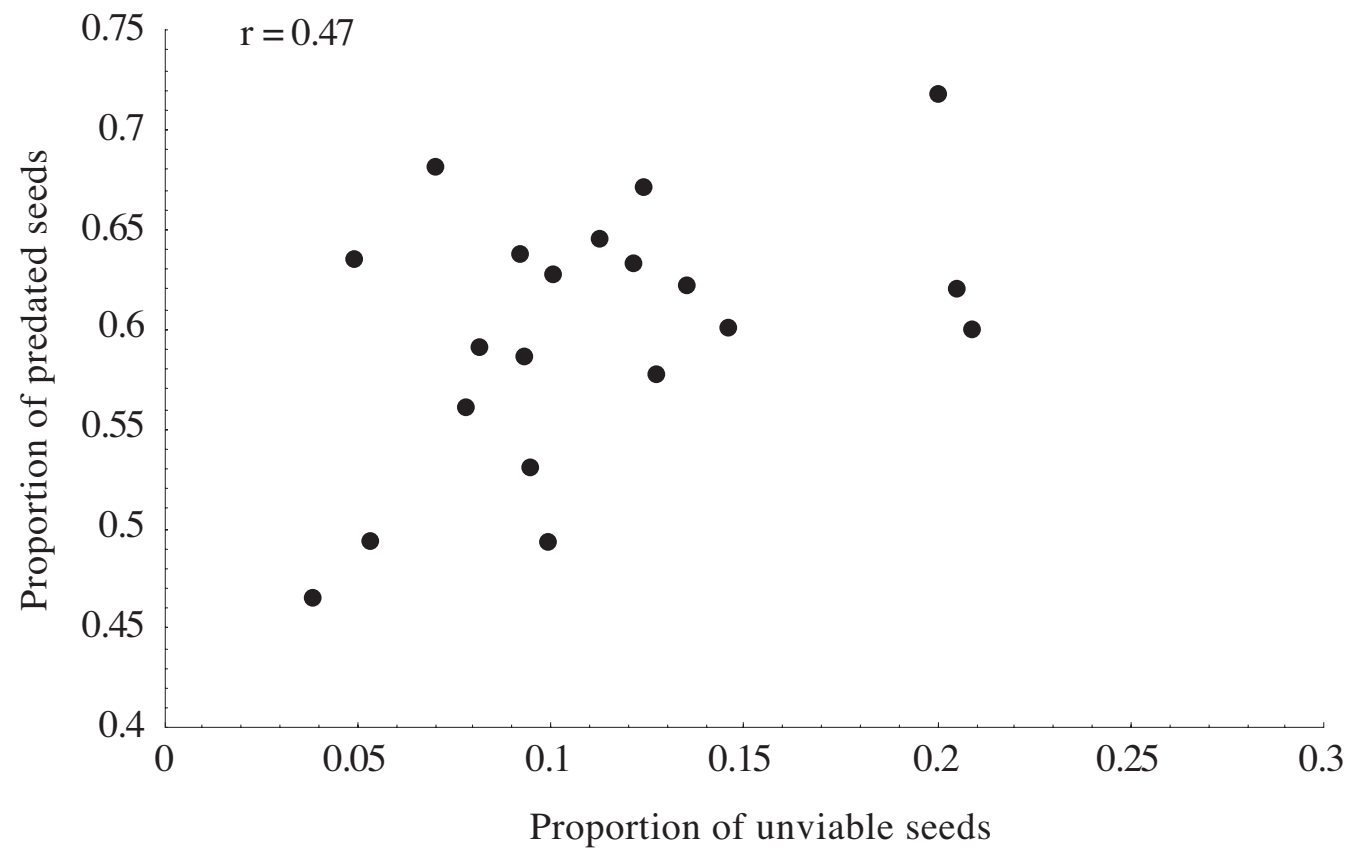

Figure 3: Positive correlation between the proportion of unviable seeds and the proportion of predated seeds among trees $[P=0.0369 ; N=20$ (results from transformed data)]. Each point represents untransformed data from a specific plant. 


\section{DISCUSSION}

Although we considered the alternating temperature $20-30^{\circ} \mathrm{C}$ as the best condition for seed germination, the impact of different temperature regimes on seed germination was similar for all tested temperatures (Fig. 2). Existing studies concerning $M$. bimucronata seed germination usually show low temperature amplitudes and the temperatures of 25 and $30^{\circ} \mathrm{C}$ were frequently used (Ferreira, 1976; Ferreira and Callegari-Jacques, 1980; Ferreira et al., 1981; Ferreira et al., 1992; Ribas et al., 1996; Fowler and Carpanezzi, 1998). However, although not significant, we observed that the lowest mean percentages of germination were reached at $25^{\circ} \mathrm{C}$ and $30^{\circ} \mathrm{C}$ (Fig. 2). Curiously, the alternating temperature $20-30^{\circ} \mathrm{C}$ was not used as a control treatment for seed germination in such studies.

In spite of the fact that temperature did not have a strong effect on seed germination, significant differences in germination among different light regimes (Fig. 1) indicate that seeds of $M$. bimucronata can be light sensitive. With respect to the effect of light on seed germination of $M$. bimucronata, more conclusive studies are needed. Ferreira (1976) reported that either the presence or absence of light did not interfere on germination of $M$. bimucronata seeds. However, we showed that germination was significantly increased under 18 hours of light, and seeds did not germinate in complete absence of light (Fig. 1). Yet, germination was significantly reduced for seeds at 24 hours of light (Fig. 1). Our findings also differ from Ferreira et al.'s (1981) study, which shows that the absence of light did not inhibit germination. However, recall that the abnormal seedlings were not considered as a successful germination in our experiments.

The germination response of a given species is assumed by studying individuals from some area that are mixed together, providing information on the average response of a population (Cruz et al., 2003). Assuming that other populations respond similarly, extrapolations are made.
However, germination responses of seeds from different sources are quite variable. Such variations may occur either between populations, different individuals in populations or different parts of the same plant (Thompson, 1975; Westoby, 1981; Silvertown, 1984; Martin et al., 1995; Schütz and Rave, 2003; Cruz et al., 2003). Therefore, not all seeds may equally germinate when exposed to certain stimuli, which may be advantageous for seedling establishment of some species that usually experience high variability in environmental conditions (Venable, 1985; Cruz et al., 2003). Results from the Ferreira's (1976) and Ferreira et al.'s (1981) studies differed in part from our findings. As seeds used in those experiments were collected from plant populations naturally occurring in the state of Rio Grande do Sul (Brazil) and we collected seeds from a plant population located in the city of Botucatu, state of São Paulo, it is possible that such differences in germination occurred due to different environmental conditions (temperature, light intensity, water supply, etc...) that $M$. bimucronata populations have been experienced for several generations.

Herbivores have been considered important agents in enhancing germination of hard seeds (Halevy, 1974; Karban and Lowenberg, 1992). For example, Takakura (2002) suggested that the specialist bruchid beetle Bruchidius dorsalis (Fahraeus) played a crucial role in the seed germination of its host plant, Gleditsia japonica (Miquel), because in some circumstances germination was facilitated after predation. In this study, however, it was shown that $M$. bimucronata seeds could not germinate when damaged by $A$. schrankiae. For seeds with large amounts of cotyledonary reserve [some tropical trees (> $5 \mathrm{~g})$ ] germination may occur even if the cotyledon is partially damaged (Dalling et al., 1997; Dalling and Harms, 1999). In contrast, $M$. bimucronata seeds may be smaller than seeds from those trees $(<0.01 \mathrm{~g}$, MN Rossi, unpublished data) and developing larva can also damage the embryo when seeds are not completely mature. Therefore, M. bimucronata seeds 
apparently cannot tolerate damages by $A$. schrankiae larvae not even before the complete larval development, this relationship being entirely antagonistic. A similar comment was presented by Takakura (2002) to explain the lack of germination of $G$. japonica seeds after being damaged by developed larvae of $B$. dorsalis.

The higher percentage of germination of seeds from non-infested fruits than from infested fruits clearly suggests that predation affects germination of viable seeds. In addition, the proportion of dead seeds was significantly increased in the infested fruits. This, combined with the significant positive correlation between the proportion of unviable seeds and proportion of predated seeds (Fig. 3), corroborates our hypothesis that $M$. bimucronata seeds can be affected by predation in several ways, at least in this studied site. The mechanisms by which predation interferes negatively on germination of viable seeds of $M$. bimucronata are not clear. Probably, they are associated with differences in the capacity of seeds from infested and noninfested fruits in allocating resources during fruit maturation. As, in the average, fruits were heavily infested in the studied site (3.88 seeds per fruit), it is possible that a considerable ingestion of essential nutrients by $A$. schrankiae larvae caused a reduction in the photoassimilate flux in fruits, which would reduce the assimilation of nutrients by the remaining seeds, thus reducing their viability. However, as water contents and dry weights of seeds did not differ between infested and non-infested fruits, biochemical studies aimed to compare the nutritional status of viable seeds from infested and non-infested fruits are encouraged in order to understand the mechanisms involved.

Our findings also have important practical implications. For example, effects of pre-dispersal seed predation on germination of viable seeds should be investigated in cultivated crops because damages caused by seed predators may be more severe than expected. Therefore, field experiments comparing germination of 'healthy' seeds from infested and non- infested fruits are needed in crops that experience high levels of seed beetle predation during fruit maturation. Another important implication of our results resides in biological control strategies of weeds. As in some cases bruchid beetles can be useful as biocontrol agents (Kassulke et al., 1990; Wilson and Flanagan, 1991), the evaluation of their efficacy should be extended by evaluating the effects of predation on viability of non-predated seeds when predation occurs in the pre-dispersal phase.

In short, this study firstly suggests that seeds of $M$. bimucronata may respond differently to germination depending of the origin of the populations. Secondly, we demonstrated that seeds of $M$. bimucronata are strongly affected by predation because predated seeds did not germinate and nonpredated seeds had their viability reduced when located in infested fruits. Therefore, we believe that this system provides an excellent opportunity to investigate many important basic and applied questions.

\section{ACKNOWLEDGEMENTS}

We thank Professor Gilson Bicudo for revising the text of the manuscript. $\mathrm{C} \mathrm{A}$ Tomaz and M N Rossi are particularly grateful to Fapesp (Fundação de Amparo à Pesquisa do Estado de São Paulo) for financial support. We are most grateful to Jeferson Klein for technical assistance, and to Cibele Chalita Martins, Laura Arruda Silva, and Rita de Cássia S M Rodella, for their advice and support.

\section{REFERENCES}

BAIER AH, WEBSTER BD (1992) Control of Acanthoscelides obtectus Say (Coleoptera: Bruchidae) in Phaseolus vulgaris L. seed stored on small farms I. Evaluation of damage. J Stored Prod Res 28: 289-293

BRASIL (1992) Regras para Análise de Sementes. Ministério da Agricultura e Reforma Agrária, SNDA/ DNDV/CLAV, Brasília

BURKART A (1959) Leguminosae. In: PARODI LR (eds) Enciclopedia Argentina de Agricultura y Jardineria. Buenos Aires, Argentina: ACME, pp: 443-512

CARDONA C (1989) Insects and other invertebrate bean pests in Latin America. In: SCHWARTZ HF, PASTOR-CORRALES MA (eds) Bean Production Problems in the Tropics. Cali, Colômbia: CIAT 
CARVALHO WA, ESPÍNOLA CR, PACCOLA AA (1983) Levantamento de solos da fazenda Lageado estação experimental "Presidente Médice". FCA/Unesp, Botucatu, SP

CASTRO J, GÓMEZ JM, GARCÍA D, ZAMORA R, HÓDAR JA (1999) Seed predation and dispersal in relict Scots pine forests of southern Spain. Plant Ecol 145: $115-123$

CRAWLEY MJ (1992) Seed predators and plant population dynamics. In: FENNER M (ed) Seeds: The Ecology of Regeneration in Plant Communities. Wallingford: Commonwealth Agricultural Bureau International, pp: 157-191

CRAWLEY MJ (1997) Plant-herbivore dynamics. In: CRAWLEY MJ (ed.) Plant Ecology. Oxford: Blackwell, pp: 401-474

CRUZ A, PÉREZ B, VELASCO A, MORENO JM (2003) Variability in seed germination at the interpopulation, intrapopulation and intraindividual levels of the shrub Erica australis in response to fire-related cues. Plant Ecol 169: 93-103

DALLING JW, HARMS KE (1999) Damage tolerance and cotyledonary resource use in the tropical tree Gustavia superba. Oikos 85: 257-264

DALLING JW, HARMS KE, AIZPÚA R (1997) Seed damage tolerance and seedling resprout ability of Prioria capaifera ('El Cativo'). J Trop Ecol 13: 617621

FERREIRA AG (1976) Germinação de sementes de Mimosa bimucronata (D.C.) OK (Maricá). Ci Cult 28 : 1200-1204

FERREIRA AG, CALLEGARI-JACQUES SM (1980) Efeito da estocagem sobre a germinação de Mimosa bimucronata (DC.) OK. and Leucaena leucocephala (Lam.) de Wit. Ci Cult 32: 1069-1072

FERREIRA AG, CALLEGARI-JACQUES SM, SCHNEIDER MVM (1981) The effect of indole acids on the germination of Mimosa bimucronata. Rev Biol Trop 29: 21-29

FERREIRA AG, LIPP-JOÃO KH, HEUSER ED (1992) Efeitos de escarificação sobre a germinação e do ph no crescimento de Acacia bonariensis Gill e Mimosa bimucronata (D.C.) O.K. Rev Brasil Fisiol Veg 4: 6365

FORGET PM, KITAJIMA K, FOSTER RB (1999) Pre- and post-dispersal seed predation in Tachigalia versicolor (Caesalpiniaceae): effects of timing of fruiting and variation among trees. J Trop Ecol 15: 61-81

FOWLER JAP, CARPANEZZI AA (1998) Tecnologia de sementes de Maricá Mimosa bimucronata (DC) $\mathrm{O}$. Ktze. Bol Pesq Flor 36: 47-56

GUREVITCH J, SCHEINER SM, FOX GA (2002) The Ecology of Plants. Sunderland, Massachusetts: Sinauer Associates

HALEVY G (1974) Effects of gazelles and seed beetles (Bruchidae) on germination and establishment of Acacia species. Isr J Bot 23: 120-126

HULME PE (1997) Post-dispersal seed predation and the establishment of vertebrate-dispersed plants in Mediterranean scrublands. Oecologia 111: 91-98

HULME PE (1998) Post-dispersal seed predation: consequences for plant demography and evolution. Perspect Plant Ecol Evol Syst 1: 32-46

HULME PE, BENKMAN CW (2002) Granivory. In: HERRERA CM, PELLMYR O (eds.) Plant-Animal Interactions: An Evolutionary Approach. Oxford: Blackwell Publishing, pp: 132-154

JANZEN DH (1971) Seed predation by animals. Annu Rev Ecol Syst 2: 465-492

JANZEN DH (1975) Interactions of seeds and their insect predators/parasitoids in a tropical deciduous forest. In: PRICE PW (ed.) Evolutionary Strategies of Parasitic Insects and Mites. New York: Plenum Press, pp: 154186

JOHNSON CD (1983) Ecosystematics of Acanthoscelides (Coleoptera: Bruchidae) of Southern México and Central America. Miscell Publ Ecol Soc Am 56: 1-248

JOHNSON CD (1990) Systematics of the seed beetle genus Acanthoscelides (Bruchidae) of Northern South America. Trans Am Entomol Soc 116: 297-618

KARBAN R, LOWENBERG G (1992) Feeding by seed bugs and weevils enhances germination of wild Gossypium species. Oecologia 92: 196-200

KASSULKE RC, HARLEY KLS, MAYNARD GV (1990) Host specificity of Acanthoscelides quadridentatus and A. puniceus (Col.: Bruchidae) for biological control of Mimosa pigra (with preliminary data on their biology). Entomophaga 35: 85-96

LORENZI H (2000) Weed Plants of Brazil: Terrestrial, Aquatics, Parasites, and Toxics (in Portuguese). Nova Odessa: Instituto Plantarum, SP

LOUDA SM, POTVIN MA, COLLINGE SK (1990) Predispersal seed predation, postdispersal seed predation and competition in the recruitment of seedlings of a native thistle in sandhills prairie. Am Midl Nat 124: 105-113

MARCHIORI JNC (1993) Anatomia da madeira e casca do Maricá, Mimosa bimucronata (DC.) O. Kuntze. Ci Flor 3: $85-106$

MARTIN A, GRZESKOWIAK V, PUECH S (1995) Germination variability in three species in disturbed Mediterranean environments. Acta Oecol 16: 479-490

MYSTER RW, PICKETT STA (1993) Effects of litter, distance, density and vegetation patch type on postdispersal tree seed predation in old fields. Oikos 66: $381-388$

NÁPOLES JR (2002) Bruchidae. In: BOUSQUETS JL, MORRONE JJ (eds.) Biodiversity, Taxonomy, and Biogeography of Arthropods from Mexico: A Synthesis. Unan, Vol. III, pp: 513-534

PICÓ FX, RETANA J (2000) Temporal variation in the female components of reproductive success over the extended flowering season of a Mediterranean perennial herb. Oikos 89: 485-492

REITZ R, KLEIN RM, REIS A (1983) Projeto madeira do Rio Grande do Sul. Sellowia 34/35: 1-525

RIBAS LLF, FOSSATI LC, NOGUEIRA AC (1996) Superação de dormência de sementes de Mimosa bimucronata (DC.) O. Kuntze (Maricá). Rev Brasil Sem 18: 98-101

SCHÜTZ W, RAVE G (2003) Variation in seed dormancy of the wetland sedge, Carex elongate, between populations and individuals in two consecutive years. Seed Sci Res 13: 315-322

SILVA LA, MAIMONI-RODELLA RCS, ROSSI MN (2007) A preliminary investigation of pre-dispersal seed predation by Acanthoscelides schrankiae Horn (Coleoptera: Bruchidae) in Mimosa bimucronata (DC.) Kuntze trees. Neotrop Entomol 36: 197-202

SILVERTOWN JW (1984) Phenotypic variety in seed germination behavior: the ontogeny and evolution of somatic polymorphism in seeds. Am Nat 124: 1-16

SOUTHGATE BJ (1979) Biology of the Bruchidae. Annu Rev Entomol 24: 449-473

STRAUSS SY, ZANGERL AR (2002) Plant-insect interactions in terrestrial ecosystems. In: HERRERA CM, PELLMYR O (eds.) Plant-Animal Interactions: An Evolutionary Approach. Oxford: Blackwell Publishing, pp: $77-106$

TAKAKURA K (2002) The specialist seed predator 
Bruchidius dorsalis (Coleoptera: Bruchidae) plays a crucial role in the seed germination of its host plant, Gleditsia japonica (Leguminosae). Funct Ecol 16: 252257

THOMPSON PA (1975) Characterization of the germination responses of Silene dioica (L.) Clariv. populations from Europe. Ann Bot 39: 1-19

VENABLE DL (1985) The evolutionary ecology of seed heteromorphism. Am Nat 126: 577-595
WESTOBY M (1981) How diversified seed germination behavior is selected. Am Nat 118: 882-885

WILSON CG, FLANAGAN GJ (1991) Establishment of Acanthoscelides quadridentatus (Schaeffer) and A. puniceus Johnson (Coleoptera: Bruchidae) on Mimosa pigra in Northern Australia. J Aust Entomol Soc 30: $279-280$

ZAR JH (1999) Biostatistical Analysis. Upper Saddle River, NJ: Prentice Hall. 